Covered in: Web of Sciences (WOS); EBSCO; ERIH+; Google Scholar; Index Copernicus; Ideas RePeC; Econpapers; Socionet; CEEOL; Ulrich ProQuest; Cabell, Journalseek; Scipio; Philpapers; SHERPA/ROMEO repositories; KVK; WorldCat; CrossRef; CrossCheck

2018, Volume 9, Issue 1, pages: 63-90 | doi: https://doi.org/10.18662/po/06

\section{Political Economy of Forest Ecology in Sierra Leone: A \\ Focus on the \\ Western Area \\ Peninsular Forest (WAPFoR)}

\section{Emerson Abraham $\mathrm{JACKSON}^{1}$}

${ }^{1}$ Doctoral Research Scholar, Centre of West African Studies, University of Birmingham, United Kingdom, emersonjackson69@gmail.com

\begin{abstract}
This article addressed historical aspects of the political economy involving sustained forest ecology in Sierra Leone as a whole, with emphasis on the Freetown Peninsula and its surrounding communities. Attention is paid to cultural, social and economic aspects involving forest livelihoods of residents on the Freetown Peninsula and far afield. The term 'Political Economy' is used in this situation to denote the relationship between the economics of people's livelihoods and public policy (in relation to the management of legislative procedures) in ensuring that resources in the forest environment is sustainably managed to cater for the livelihood needs of people in Sierra Leone, while at the same time maintaining a balance in protecting the forest ecosystems. The paper has provided a critical review of the political economy of forest ecology in the country on the basis of scholarly discourses, and its applicability in adapting to the fragile political administrative management Sierra Leone have (and is continuing to) experienced.
\end{abstract}

Keywords: Political Economy; Forest Ecology; Critical Discourse; Sustainability; Sierra Leone.

How to cite: Jackson, E.A. (2018). Political Economy of Forest Ecology in Sierra Leone: A Focus on the Western Area Peninsular Forest (WAPFoR). Postmodern Openings, 9(1), 63-90. https://doi.org/10.18662/po/06 


\section{Introduction: Historical Perspectives of Sierra Leone}

Sierra Leone as a country was established by an English humanist, Granville Sharp, to "repatriate" former slaves; a multi-ethnic and multilinguistic groups of people, and together created a new set of social and ethnic community in the capital city (a derivative of Freedom), now popularly known as the Krios (July, 1970), (OECD, 2010). Sierra Leone as a nation consists of 149 constituent chiefdom established in 1986 under the premiership of Governor Cardew who empowered a set of 'Paramount Chiefs' as the sole authority of local government in the newly created Protectorate; the colony of 'Freetown' and the chieftaincy system were the only recognised system of governance in the country. In 2004, a World Bank donated funds eventually resulted in the establishment of a local council systems (Reed \& Robinson, 2013).

Prior to independence in 1961, the colony of Freetown was governed by elected local government under the British legal system, while the rest of the country (registered as Protectorate) continued to be governed under chieftaincy (OECD, 2010). The legacy of the divided country (Protectorate and the newly created Colony of Freetown) is still dominating governance structure in the country; this resulted in a heightened level of ethnic tension, and now an unprecedented level of selfishness demonstrated across the country.

The first election for an administrative governance in the entire country was held in 1962, which also left the country divided on ethnic grounds, with series of coup plots (all in the late 1960s to 1980s), under the premiership of the All Peoples Party (APC), headed by the late Dr. Siaka P. Stevens, and later in the 1980s with the transfer of power to the late Brigadier Joseph Saidu Momoh (OECD, 2010) - the emergence of the National Provisional Ruling Council (NPRC) made its presence in governance during the brutal ravaging of the country's infrastructural and economic fabrics by the insurgence of the 'Revolutionary United Front (RUF), which then finally spearheaded the transition to a properly elected system of democratic governance, after a legacy of brutalised tenure experienced by people in the country (Commission, 2004), (Suma, 2009). The RUF is the remnant of disgruntled group of guerillas (headed by Fodau Sankoh, and was heavily financed by the Liberian rebel leader, Charles Taylor) who had no respect for humanity, but with intent on destroying the entire country's entire structure, which is still impacting on the slow pace of development the country is struggling with at present (Suma, 2009). 


\section{Rationale, Specific Objectives and Methodological Orientation}

Sierra Leone is a naturally endowed economy, particularly in (non)renewables like forest products, highly accessed by (poor) rural community residents for livelihood purposes and also as a means for GDP / revenue generation through extraction and sales of timber and pole (E. A. Jackson, 2015b, 2015c). The country's forest sector has gone through transformation since independence from its colonial master, the United Kingdom; this is attributed to multiplicity of problems, for example, the rebel war which erupted in the early 1990s, thereby giving rise to a massive population mobility into areas like the Western Area Peninsula Forest (WAPFoR). Therefore, in a bid to understanding some of these issues, this article has taken a critical approach to the political economy of forest ecology in the country, with the following specific objectives:

- Examine the geography and demographic structure of the country in a bid to understanding the nature of forest dynamics in the country as a whole, with particular focus on the WAPFoR area.

- Provide critical discourse based on scholarly literature around the political economy of Sierra Leone, since independence.

- Assess the country's approach to a sustainable forest policy management.

The methodological approach to this study is based on (critical) literature review of scholarly materials pertaining to the political economy of forest policy management in Sierra Leone prior to and post-independence, but with 'bermenentic' focus; the concept is rooted in Philosophy, a form of interpretative study of text or documents, originally linked to the study of biblical exegesis and interpretation of the law (Conteh, 2013; E. A. Jackson, 2016; E. A Jackson, 2016; Jackson \& Conteh). Hermeneutics in this [as opposed to its biblical origin] refers to the methodology and art of interpretation (Kinsella, 2006) which in this case, an expounded critical discourse of historical events of forest livelihood events around the WAPFoR area.

\section{Geography and Demographics}

\subsection{Location, Geography and Climate}

This is an important area in the pursuit of understanding the dynamics of the politics and forest management process in Sierra Leone, where an estimated 39\% of the country is thought to be covered with forest, scattered in different location across the country, but more heavily in the eastern region and around WAPFoR territory (USAID). 


\subsubsection{Location}

Sierra Leone is a small country located along the west coast of the African continent and as descriptively outlined by Konteh, 1997 and UNEP, 2010:

"it lies between latitude 6 degrees, 55 minutes and 10 degrees north, and longitudes 10 degrees and 13 degrees west. With a total area of 72,326 sq. km (27,699 sq. miles), it is compacted with approximately $346 \mathrm{~km}$ from north to south, and from east to west. The country is bordered to the southwest by the Atlantic Ocean, and with Liberia to the south-east and Guinea on the north and northeast (Figure 1) - there are four provincial towns namely, North, South, East and West (WAPFoR), and 14 administrative districts".

\subsubsection{The Country's Geography}

The country is made up of four geographical zones (UNEP, 2010b) "the interior plateau (generally flat and makes up approximately $40 \%$ of the country's surface, extended from north to south, and scattered with mountains mainly in the north and Eastern parts of the country), lowland plains (bordered with plateaus running down to the coastline, which makes up $43 \%$ of the country's area), coastlines (sloping and extends over $400 \mathrm{~km}$, comprising of mangrove swamps, beaches, terraces and ridges), and mountains (generally WAPFoR interspersed with forested hills)".

\subsubsection{Ethnic Composition in Sierra Leone}

Figure 1: Sierra Leone's Ethnic Composition

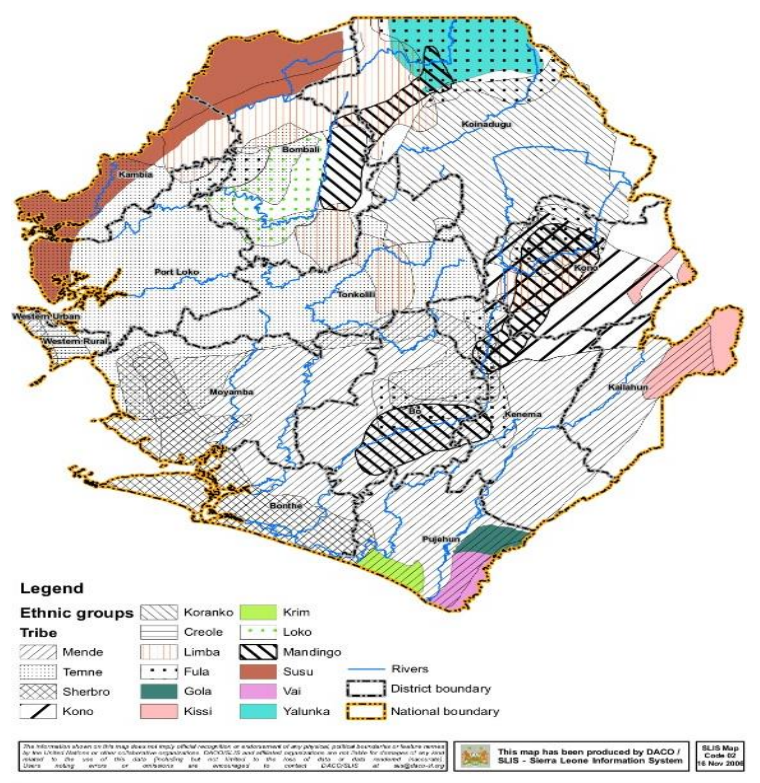

Sierra Leone is a small country with just over 6 million people, and a composition of 16 different ethnic groups. The Map below (Figure 1: Sierra Leone's Ethnic Composition) provide an illustrative distribution of the country's ethnic groups. Based on evidence from 'Visit Sierra Leone' (Leone, 2015) website, the composition is explained thus:

"The largest of these is the Mende, mainly found in the Southern and Eastern Provinces. The second highest ethnic group are the Temne's in the North; third in the group are the 
Limba's, also in the Northern Province, and followed by the Kono in the Eastern Province. Other minority groups include the Koranko in the North as well as Yalunka, Loko, Soso (Susu), Madingo and Fula. On the coast, north and south are the Bullom and Sherbro followed by the much smaller groups of Krim, Vai, Gola, with the Kissi further inland in the Eastern Province. The Western area, including Greater Freetown and the Peninsula, is a mixture of population groups, but home to the Krio's, repatriated slaves."

\subsubsection{Climate}

The country's climate is generally humid with two distinct seasons (Figure 1: Sierra Leone's Ethnic Composition) - "rainy and dry; the rainy season runs from May to October, rainfall generally varies with the relatively drier north and northeast region, approximately 2,500-3,000 millimetres per year, to the southeast and 5,000 millimetres per year in the Western Area Peninsula); the dry season last from April to November, with varying degree of dryness and interspersed with the Harmattan - daytime temperatures range from 25 to 34 degrees Celsius, temperatures generally drop as low as 16 degrees Celsius during the Harmattan. There are two types of climate zones in Sierra Leone, with most of the country classified as 'tropical monsoon' and a thin belt of 'tropical savannab' along the northern border with Guinea. (Konteh, 1997) and (UNEP, 2010b), (UNIPSIL, 2006).

\subsubsection{Population Characteristics and Vital Statistics}

The population of Sierra Leone as shown in Table 1 (Sierra Leone Vital Statistics) is approximately 6 million based on the last census statistics (2008). The rural population is almost twice as higher than the urban population, which is reflected on the limited opportunity for people to access jobs, and historically, the dependence of people (in rural communities) on forest resources as an easy means to livelihoods. The approximate $70 \%$ poverty data is indicative of multiplicity of issues like low educational attainment, limited opportunity for people to compete for high flying jobs, but more so as in the case with Sierra Leone, the legacy of the brutal civil war which infiltrated into the entire fabrics of the system (social, economic and environmental), with forest communities targeted as a source of exploitation to fund guerilla activities.(UNEP, 2010a).

\section{Table 1: Sierra Leone Vital Statistics}

Population

$\sim 6$ million

Urban / Rural

30-40 percent/60-70 percent 


\begin{tabular}{|l|l|}
\hline GNI per capita & USD $666(\mathrm{PPP})$ \\
\hline Acute poverty & $>70$ percent \\
\hline Inequality & $\begin{array}{l}\text { Richest } 20 \text { percent does }>63 \text { percent of } \\
\text { spending }\end{array}$ \\
\hline $\begin{array}{l}\text { Human Development } \\
\text { Index }\end{array}$ & 0.336 \\
\hline Ranked & $179 / 179$ \\
\hline Source: UNEP, 2010 & \\
\hline
\end{tabular}

There is high growing inequality in the country, with the poor still finding it hard to cope with basic livelihood requirements, while reliance on foreign aid is seen as a means to an end in funding essential activities by the government (IMF, 2009). Ranked at the bottom of the country profile table, with the human development index of 0.336 , is quite low given the natural resource endowment capability of the country.

\section{Political Economy of Forest Policy in Sierra Leone}

Forest is undoubtedly playing a great role in Sierra Leone's communities, and according to Alieu (E.K. Alieu, 2001) about $80 \%$ of the population in rural rural areas consume 6.2 million $\mathrm{m} 3$ of firewood; 396,000 $\mathrm{m} 3$ wood equivalent of charcoal; 43,200 m3 of fence sticks and 252,000 m3 of timber for construction, cooking, heating, etc., per year. In greater Freetown of Sierra Leone alone, particularly in the Freetown peninsular, it has been noted that over 70 plant species have been identified for plant medicine and dye, while the gabbage of the young palm tree, bush Yams [Discorea] are also important hungry season's food for local residents (E. A. Jackson, 2015a), (Mula \& Saxena, 2010), (E.K. Alieu, 2001; E. K. Alieu, 2011; E. A Jackson, 2016).

It is also noted that "during the next 2 decades, the area of legally constituted forest estates will continue to decrease due to urbanisation and forest degradation, which will permanently change land use; about $10 \%$ of the country's land area (both government controlled estate and salvage) comprising of closed forests will be deforested at the rate of about 1.5-2.0\% per annum, thereby increasing the area under forest re-growth currently occupying $60 \%$ of the country's total land area (E.K. Alieu, 2001; E. K. Alieu, 2011).This has given rise to direct consequences on livelihoods, 
particularly for poor rural residents in forest communities on the Freetown peninsula areas of Goderich-Tokeh (E. A. Jackson, 2015a) The escalated scale of depleted forest caused by massive urbanisation and settlement in the Freetown peninsula area is creating serious impact on survival of local residents, and even social, cultural and environmental well-being (E. A. Jackson, 2015) (Deen-Swarray, Adekunle, \& Odularu, 2013).

The management of forest ecosystems has been a topical discourse as early as in the colonial era (under the British control), while the continued scale of deforestation and forest degradation remains a highly politicaleconomy issue, with forest considered one of the main source of livelihoods for rural residents (Wardell \& Lund, 2006), (Mvondo \& Oyono, 2004), (P.G. Munro \& Horst, 2011; Oyono, 2005), (E. A. Jackson, 2015). A widely supported view of Eurocentric Malthusian theory of population by policy makers in developing nations in Latin America, Southeast Asia and Africa (Sierra Leone not being an exception) has made things more difficult in terms of the conflicting views of policy makers to protect the environment (through activities like deforestation) on one hand, and that of rural community residents' whose main focus is geared towards securing avenues for a sustainable means of livelihood (M. Leach \& Fairhead, 1994, 1995). In view of Munro and Horst's (P.G. Munro \& Horst, 2011) study on the political ecology of forest policy in Sierra Leone (Akiwumi, 2006a, 2006b; M. Leach \& Fairhead, 1994), an examination of 19th century lumber exports clearly show that poor accountability in record keeping, and also high level of smuggling could also be some of the contributing factors of the dwindling state of forests as opposed to the acclaimed assertion of over-exploitation by rural community residents and others far afield.

Even the establishment of forestry department across the African region, and particularly in Sierra Leone after the 'scramble for AFRICA' in the 1890s was seen as a means of protecting the environment from exploitative usage (as manifested in legislative policies related to forest laws); its authenticity is still being criticised by scholars as a mere means of fooling the international community; an easy approach to the exportation of forest timber products to western economies, particularly in Europe (more so, the UK as in the case with shipments from Sierra Leone) in achievement of their adventured dreams of profitability (in the case with corporations), and the balancing out of national accounting for the benefit of the state (P.G. Munro \& Horst, 2011), (Meredith, 1986), (Davis, 2005; Lane-Poole 1911), (Becker, 2001). An established researcher in the area of forestry studies was able to confirm his investigation in relation to the UK government's establishment of the legal arm of the forestry department, which is seen as 
purely a means of reinforcing their hegemony, an easy means of exploiting the natural resource endowment of the country; local means of use of the forest (more so in pursuit of livelihoods) was discouraged, but with laws favouring the active promotion of European style exportation of timber produce (particularly after the establishment of the Saw-Mill factory, see Munro, 2009 (P. G. Munro, 2009), with original citations in (Lane-Poole 1911), (Unwin, 1909). into the UK and EU commercial markets. An excerpt quotation from Munro and Horst (P.G. Munro \& Horst, 2011), also in Alldridge (Alldridge, 1910) outline an overt expression by a British Government's Travelling Commissioner in Sierra Leone during that time as illustrated thus:

"Of course where Nature has been so lavish the natives are content with what they find to hand; it needs European intelligence to see what further wealth could be produced by cultivation, and to discover the uses to which the cultivated article could be applied, as well as a knowledge of the markets in which it could be sold".

The political economy of forest management in present day Sierra Leone needs thorough review, with clear focus in incorporating the complex dynamics of culture / traditions and the prevailing global dynamics so as to make it worthwhile for the entire forest ecosystem to serve its beneficial purposes of livelihoods (first and foremost, meeting the needs of rural residents, and as a secondary means for commercial purpose, but which may also help in providing some form of access to livelihood assets for the benefit of locals) and the conservation of the environment through loss of high level of carbon emissions and climate change impacts. As identified by Jackson (E. A. Jackson, 2015b) even though nationals, more so high profile government officials have all been engaged in the deliberate exploitation of forest resource in Sierra Leone (through timber trade), it is quite clear that (Alldridge's criticism of Eurocentric approach on forest policy formulation) (Alldridge, 1910) policies, for example FLEGT. are not favourably monitored to expose culprits, but more to the advantage of multinational corporations in developed economies, thereby leave nationals and rural residents in particular at the fringe of being disadvantaged with little or no chances of gaining easy means of access to their local forests in pursuit of livelihoods.

In the case with Sierra Leone, forest is utilised by different (ethnic) groups for varied purposes; majority of the time, it is done in pursuit of meeting livelihood needs - while the insurgence of RUF incursion (involving the recruitment of child soldiers) into the Sierra Leone territory shows how complex the politics of forest management can be, with its varied resources 
targeted by some as a way of finding easy means of paying for senseless causes (Kaimowitz, 2003; USAID).

\section{Colonial and Post-colonial Forest Management Strategies}

The management of forest in Sierra Leone is considered a historic process and this include the colonial and post-colonial eras. The colonial era is the period of time when the country was under the jurisdiction of the British (UK) government and every aspects of forest use was being determined by approval of HM Royal. Following this period, that is postindependence (1961), all activities in the country were managed by constitutional authorities in Sierra Leone, under the direction of the Forestry ministry.

\subsection{Colonial Forest Management}

Colonialism in Sierra Leone (under the British rule) commenced in 1808, at the time when the enclaved Freetown became a 'Crown Colony'; prior to that, in 1778, it was used by a group of British philanthropist (also referred to as the Clapham Sect) to establish settlement for freed slaves (Dorward, 1981).

During the colonial era, various laws were enacted by the then authorities between 1808-1912 (the earlier part which was the pronouncement of the crown colony) and prior to this period, Sierra Leone had no laws governing use / access to forests; the first of such move was done in 1911 with the appointment of Lane Poole to look into the extent of deforestation (which he blamed on recklessness of local people through deliberate acts of shifting cultivation), which was seen as a way of curbing the purported accusations ((Konteh, 1997) (Ribot \& Cline-Cole, 1997). According to MacGregor (MacGregor, 1942) the exploitation of the country's forests for timber trading was not documented in Lane's report (Lane-Poole 1911), which was very well embellished on account of $99 \%$ loss to the Sierra Leone's rainforest being depleted, when in fact the exploitation had been on-going as early as in 1816, around the Bullom Shores, Great Scarcies and Portloko by well-known British entrepreneur by the name of John McCormack.

Forest activities in the colony was very active with the emergence of the Europeans, particularly the British in the Sierra Leone territory, who saw it as an easy way of enforcing their hegemony through the enactment of legal proceedings which prohibited people from relying on rich forest resources (for their livelihoods) - this was stampeded with the establishment of the Forestry department and also the enactment of the country's first ever forest 
laws in 1912 (Cole, 1968), (M. Leach \& Fairhead, 2000), (P. G. Munro, 2008) (FD/SL, 1913). In January 1922, the Agriculture department was amalgamated with forestry as the two were thought as being too closely related in their activities, but most importantly, in a bid to reduce costs on the then colonial leadership in Sierra Leone after the loss of revenue from natural produce (particularly from forestry and agriculture) subsequent to the harsh impact felt from World War 1 (Dorward, 1981). The legacy of a divided country, with a colony (now Western Area incorporating WAPFoR) and the protectorate is still a resonating memory in the collapsed state and mismanagement of the natural resource sector in Sierra Leone.

\subsection{Post-colonial Forest Management Strategies}

Post-colonial era marked the period after independence in 1961, which then witnessed more of the enforcement of protected areas of forest reserves (with reference to Table 2: Protected Area). The protection of forest land in the country is under the direction of the Forestry division at the Ministry of Agriculture, Forestry and Food Security (MAFFS), and more lately, the support of allied organisations like the Environmental Protection Agency (EPA) and the National Protected Area Authority (NPAA) (E. A. Jackson, 2015c).

\begin{tabular}{|l|l|l|l|l|}
\hline \multicolumn{2}{|l|}{ Table 2: Protected Area } \\
\hline $\begin{array}{l}\text { Protected } \\
\text { area }\end{array}$ & Status & Size (ha)3 & District & Description \\
\hline $\begin{array}{l}\text { Outamba } \\
\text { Kilimi }\end{array}$ & $\begin{array}{l}\text { National } \\
\text { Park }\end{array}$ & 110,900 & Bombali & $\begin{array}{l}\text { Part of the transboundary } \\
\text { Fouta Jallon Highlands where } \\
\text { six of West Africa's major river } \\
\text { rise. }\end{array}$ \\
\hline $\begin{array}{l}\text { Goal } \\
\text { Rainforest }\end{array}$ & $\begin{array}{l}\text { National } \\
\text { Park }\end{array}$ & 7,107 & $\begin{array}{l}\text { Kailahun, } \\
\text { Kenema, } \\
\text { Pujehun }\end{array}$ & $\begin{array}{l}\text { The last significant patch of } \\
\text { closed canopy rainforest in } \\
\text { Sierra Leone. }\end{array}$ \\
\hline $\begin{array}{l}\text { Western } \\
\text { Area } \\
\text { Peninsula } \\
\text { Forest }\end{array}$ & $\begin{array}{l}\text { Non- } \\
\text { Hunting } \\
\text { reserve }\end{array}$ & 17,688 & $\begin{array}{l}\text { Western } \\
\text { Area }\end{array}$ & $\begin{array}{l}\text { Forest on the hills outside } \\
\text { Freetown which provides much } \\
\text { of the capital's fresh water } \\
\text { supply. }\end{array}$ \\
\hline $\begin{array}{l}\text { Lima } \\
\text { Mountains }\end{array}$ & $\begin{array}{l}\text { Non- } \\
\text { Hunting } \\
\text { reserve }\end{array}$ & 33,201 & Koinadugu & $\begin{array}{l}\text { Site of the country's highest } \\
\text { mountain, Mount Bintumani } \\
\text { (1,948 metres). }\end{array}$ \\
\hline
\end{tabular}


Political Economy of Forest Ecology in Sierra Leone: A focus on the Western ... Emerson Abraham JACKSON

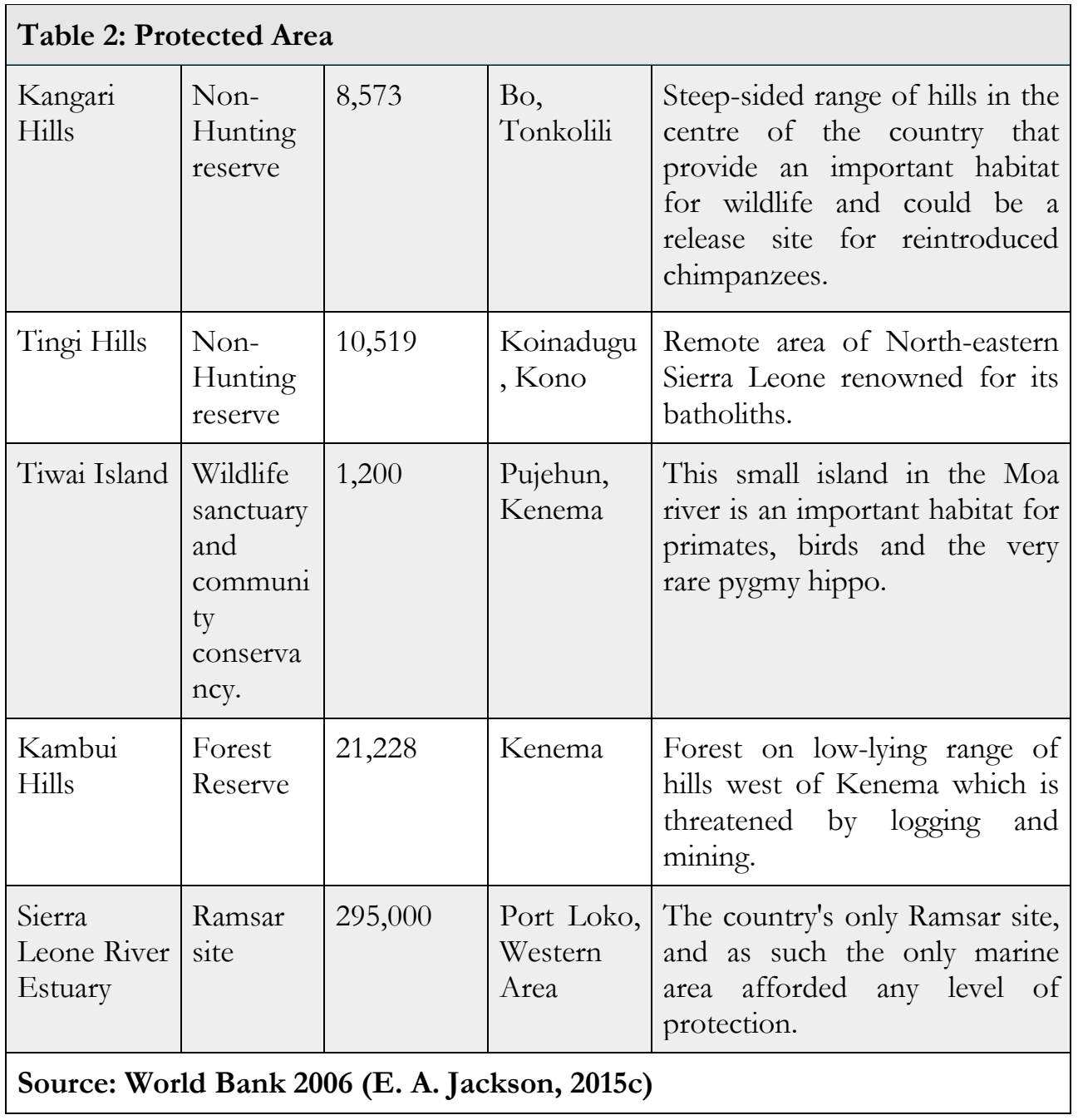

According to Alie (n/d), the mandate of the forest department is to 'promote sustainable forest management through "wise use" of the country's natural resources'. The sustainable forest management phrase is used in this context as a means or measure, for example, the incorporation of institutionalised legislations, and in some cases, physical protection to deter access set in place to assist with the preservation of forest locations so as to ensure it meets the livelihood needs of those who rely on it for their daily means of survival without destroying the ecosystems. In order to promote the division's goal of managing the forest ecosystems effectively, a move towards decentralisation as opted for (consistent with the decentralisation 
act 2004), with breakdown into four branches, namely, Wildlife Conservation, Forest Conservation Research Branch (silviculture), and the privatised Rubber development (E.K. Alieu, 2001).

Equally, the establishment of legislative measures, at different point in time on the country's forest management goal is making an impact, and according to Jackson (E. A. Jackson, 2015c), these include the following:

- Wild Life Conservation Acts,1972: Since independence in 1961, Sierra Leone have struggled in her capacity to manage its (forest) natural resources, due to lack of a sustainable protection policy. According to IUCN (IUCN, 1993) the act identifies six protected area categories, namely 'National Park, Strict Nature Reserve, Game Reserve, Game Sanctuary, Controlled Hunting Area and Non-bunting Forest reserves'.

- Forestry Act (June1988): This gives MAFFS, and in particular the Forestry division the power to protect and conserve water, soil, flora and fauna. This prohibit activities dealing with the falling of trees and also granting of restricted license by the director of conservation to remove a protected tree (USAID, 2007). This act provided an opportunity for the then forestry ministry to establish room for the protection of valuable forest locations, and most importantly, the reforestation of land which were considered to have gone through considerable exploitation / degradation. Within the legal provision of the act, it was forbidden for people or institutions to cut or even burn trees found within defined locations of what is typically classified as forest, except with the permission from the Chief Conservator of forest, on whose approval licenses were granted. This act despite been considered as a step forward, was poorly applied in practice, more so, due to poor monitoring by officials from the forest division at MAFFS, which then lead to one of the highest level of illegal access, particularly in the protected areas ((Konteh, 1997), (G. o. S. L. GOSL, 1989).

- National Biodiversity Strategy and Action Plan (NBSAP, 2003): This was prepared as an obligation to meeting the UN convention on Biological Diversity. It is a safeguard measure to both terrestrial and aquatic biodiversity aimed at providing a firm framework for the benefit of present and future generations'. The NBSAP is also an advancement in the move to protecting biodiversity loss and the prevention of forest degradation.

- The Environment Protection Act 2000 and the Environmental Protection Agency (EPA) Act 2008: both of these acts were geared towards the protection of the environment, and which include the forest ecosystems. The EPA Act 2008 was more enforceable as it allowed the agency to procedure perpetrators who were willfully working against the law, 
particularly in the destruction of the environment, which in effect would impact on livelihoods and the demise of biodiversity.

In addition to the above mentioned acts, officials and professionals on behalf of the government have taken a step forward by adding new draft laws which is the 'Conservation and wildlife Policy and Forests Policy Acts (Brown \& Crawford, 2012) this "sets out five principles which include species management, conservation areas, research and monitoring, education and awareness and capacity building (E. A. Jackson, 2015c). A late emergence on the drive to securely manage the sustainability of the forest ecosystems in Sierra Leone is the 'National Protection Area Authority and the Conservation Trust Fund (NPAA) Act 2012. This is also an arm of MAFFS, with the mandate of managing all areas dealing with improvement on the environment, and more so, ensuring (forest) protected areas are effectively managed from abuse by the public (E. A. Jackson, 2015a).

In as much as the criticism raised about colonial hegemonic act of domination in controlling Sierra Leone's natural resources (particularly the forest sector, to name a few, easy timber export) is dominating scholarly critical discourses, attitudes of nationals, and more so the brutal rebel war that ravaged the economy, has exacerbate the dwindling state of forest reserve in the country to its current patchy state (Munro, 2009, an original citation in Baker et al. 2003).

\section{Wars as drivers of failed Forest Policy in Sierra Leone}

According to Beevers, (Beevers, 2012), (De Jong, Donovan, \& Abe, 2007), there is strong correlation indicating that nearly half of conflicts in the 20th century is linked with forested regions, mostly in tropical countries. Perspectives from scholars like Homer-Dixon (Homer-Dixon, 1991) and Kaplan (Kaplan, 1994) testify the fact that forest degradation and high population growth, backed by poor forest management (particularly in poor tropical rich forest economies) have intensified violent tendencies towards people's innate ability to protect territories associated with their livelihood space. Scholars like Ross (Ross, 2003) have also subscribed to the fact that countries endowed with natural resources have higher tendencies for people to engage in conflicts as it is purported to be a base for selfish individuals to exploit easy means of livelihoods through access to variety of resources like timber export.

Sierra Leone is a small country with a population of just about 6 million (Table 1: Sierra Leone Vital Statistics), and endowed with valuable land/based natural resources (such as diamonds, rutile and timber based 
products like rubber and pole) - evidence revealed that the rich attraction of these resources is an influencing factor for the prolonged fighting which Sierra Leone experienced for over a decade, between 1991 - 2001 (P. G. Munro, 2009; UNEP, 2010a). According to Beevers, 2012 (Beevers, 2012) (Reno, 1998, 2000), evidence also points to the fact that exclusive dependence on timber income (particularly in tropical under-developed economies) is likely to create weak state governance due to high possibility of selfishness (argument based on the 'Resource-Curse Hypothesis and Dutch Disease', critiqued by scholars like Rosser, (Ebrahim-Zadeh, 2003; Rosser, 2006) and a possible incitement for violence - the case of $\mathrm{Al}$ Jazeera's under-cover investigation about high profile corruption in timber trade in Sierra Leone is also an attestation of this situation (E. A. Jackson, 2015; E. A. Jackson, 2015b).

\section{Sustainable Livelihood and Forest Management Nexus in Sierra Leone}

Shahbaz (Shahbaz \& Suleri, 2009) and highlighted two overarching issues based on contemporary literature about linkages between rural livelihood security and forest management, and these include:

- how and to what extent forest resources can contribute to poverty alleviation.

- how and to what extent poverty alleviation and forest conservation can be made convergent rather than divergent goals".

Forest plays a very important role in the lives of rural communities in Sierra Leone, more so given the fact that poverty is an endemic thing in the country. Current legislations in relation to access to forest in the country is posing serious problems in terms of the sustainable livelihoods of people, for example, legislative measure such as those stipulated according to the forest laws of Sierra Leone (Forest Acts 1988 and more lately the NPAA) means that people, particularly those in rural communities are more or going to find it hard gaining access in seeking for basic livelihood needs.

In a bid to striving for sustainable livelihood target, the government through its administrative arm (MAFFS), have been working hard since 2008 at restructuring the forestry division to incorporate 'Commercial Forestry, Conservation \& Wildlife Management and Community Forestry', headed by an Assistant Director of Forestry as shown below in Figure (Amazon Web Services, $\mathrm{n} / \mathrm{d}$ ). In order to move on with the government's mission of meeting its priority in protecting the forest ecosystems, and in addition addressing the livelihood and poverty state of forest community dependents, 
a national workshop was convened in the early part of the year 2009 (precisely 3rd - 5th February) and backed by international organisations and NGOs like the European Union (EU) and the United States Agency for International Development (USAID) to review existing policies, laws and regulations of forestry division in the country as a whole - outcomes of this resulted in the formation of an Advisory Committee (AC) incorporating representatives from various groups (Forestry division at MAFFS, International and Local Organisations, Civil Society and Local Community Groups), with the ultimate goal of achieving two policies to address 'forestry and wildlife conservation' (Amazon Web Service, $\mathrm{n} / \mathrm{d}$ ). The positive thing about the consultation was an efforts geared towards engaging the wider public (through national broadcast in the most widely spoken vernaculars, Krio to keep people informed about the AC's decision, the expectation that outcomes from the consultation would address parts of the constitution of Sierra Leone as outlined below, an excerpt from Amazon Web Service (n/d):

[Section 7(1)a], which is simply the "harnessing all the natural resources of the nation to promote national prosperity and an efficient, dynamic and self- reliant economy"

[Section 11.3.2)], geared towards the reduction of forest degradation and the conservation of biodiversity and this specifically is also in support of the "Sierra Leone Poverty Reduction Strategy II, "Agenda for Change" (PRS II), which identifies poverty alleviation and environmental management nexuses.

[Section 11.4], part of that PRS11 obligation to address the sustainable management of forest resources in reducing poverty through the encouragement of activities like Ecotourism, community forest management, and the commercialisation of forestland (involving activities like lawful timber trading which is in line with the international FLEGT standards).

The above expression in supporting the effective management of forest to promote sustainable living seemed good in paper - but how far does it go in terms of addressing the livelihood needs of poor people in Sierra Leone is critically contentious? As already addressed in earlier section, the country is highly divided on the basis of the division created by the colonial power (P. G. Munro, 2008, 2009), and which makes it very difficult for poor people (particularly rural and indigenous forest community residents) across the country to fully harness resources to meet their daily livelihood needs - heavily focus on the commercialisation of forest lands have seen the exploitation of timber products by both high profile nationals through connivance with international corporations to exploit the country's rich national environment, while the environment is left in destructive tatters, and with community dependents left to struggle for their daily 
survival (E. A. Jackson, 2015b), (P. G. Munro, 2009). On the basis of Phronesis (the manifestation of 'good or bad' virtuous actions), a rational being may easily jump into conclusion in justifying the upsurge of violence, which gave rise to a decade of brutal civil war, and for forest lands across the country were seen as easy target for rebel fighters to target because of their endowed assets which were sold to purchase arms (E. A Jackson, 2016; E. A. Jackson, 2016), (UNEP, 2010a).

This brings one closer in addressing Shahbaz and Suleri's (Shahbaz \& Suleri, 2009) concerns / issues (how and to what extent poverty alleviation and forest conservation can be made convergent rather than divergent goals). Current policy focus in Sierra Leone is heavily directed at the conservation of forest environment which is quite good, particularly in addressing environmental concerns, but the scope for sustainable livelihood is actually not consistent with the requirements of international standard; forest community residents are the most vulnerable when it comes to policy implementation relating to restricted forest usage. In view of legislative acts pertaining to the protection of forest in Sierra Leone (more so the latest of which is the NPAA act 2013), there is hardly any substantive information dealing with the sustainable use of the forest environment that favour the protection of local residents (Guide). These are all meant to salvage the remains of the destructive environment rather than converging it with the livelihood needs. As in the case with Sierra Leone where poverty is rather high, access to forest by locals is seriously threatened, while at the same time ensuring that their usage is done in a sustainable way to ensure the forest ecosystems is effectively managed without much of a destruction to existing biodiversity. This required properly trained and qualified personnel (from the forest division at MAFFS) and supported by other national groups to help address the ongoing problems of forest loss and risks to the sustainability of livelihoods from forest resources.

\section{WAPFoR Demographics, Cultural Ties with Forest}

Freetown Peninsular is an area endowed with forest reserve, particularly along coastal towns of Goderich-Tokeh, and with much of it accessed by local residents for survival through activities such as palm wine tapping (an activity mostly carried out by the Limba's) wood fetching for domestic usage for sales to generate income for daily survival (E. A. Jackson, 2015c), (P.G. Munro \& Horst, 2011), (Cole, 1968) (Konteh, 1997; Lebbie, 2000) the extraction of herbal leaves for medicinal purposes and cultural activities involving Bundo initiation and hunting to exhibit cultural ceremonies (Bosire, 2012; E. A. Jackson, 2015a, 2015b) It is also used as a 
means for local societies to perform rituals [like hunting and initiation ceremonies by the BONDO society], fishermen to carve canoes (Bosire, 2012; E. A. Jackson, 2015a). Most importantly, the reserve in the mountainous areas of Guma also serves as a means of protection from erosion, conservation for water, etc.

The Freetown peninsular coastal / seaside towns [covering Goderich to Tokeh] are the first scenic view for someone entering Sierra Leone by Sea, and for which the name Sierra Leone [Sierra Lyoa] originated in 1460s by a Portuguese explorer meaning Lion Mountain (Conteh, 2013), (Mark, 2007). Because of its location, it is also a means of tourist attraction and wild life reserve.

\section{Forest Tenure}

Forest tenure in Sierra Leone falls within the remit of the state / central government, and in the case with the protectorate, it is the responsibility of the chieftaincy - in some situations, private companies or groups may be allowed to own forest, but with the ultimate goal of promoting economic prosperity, which normally does not work in the best interests of those who needs to protect their livelihood vulnerability (Unruh and Turay 2006), (Dale, 2008). In the protectorate where land is in the control of the chieftaincy, land ownership is in the possession of family members or generation yet unborn who are heirs to such land; in cases where land is owned by a foreigner or a settler (not considered to be of birth right), such lands are normally leased with arrangements made for annual fees to be paid through administrative means (Unruh and Turay 2006). Majority of the state owned forestland are under protection, particularly so in monitoring protection of essential biodiversity or reserved for communal usage, as in the case with parks serving the purpose for ecotourism (FAO, 2005).

\section{Community-based Natural Resources Management in the WAPFoR} Area

These are practices that have emerged in discourses around the management of forest ecosystems; an approach used to support local participation in their environment, while seeking avenues for decent livelihoods. As explained by Hajjar (Hajjar, 2011), the concept of community forestry is now associated with concept such as agroforestry and community-based forestry (addressed in this work), particularly in promoting sustainable livelihoods for locals in the WAPFoR area. It is factual from 
research work carried around the world that community forest yields substantial benefits to communities, which in most cases include 'economic, socio-cultural and ecological (Hajjar, 2011), (Agrawal \& Gibson, 1999; Glasmeier \& Farrigan, 2005)

There has been a blame culture problem (much more so used by mainstream government departments, namely Ministry of Land and MAFFS) in Sierra Leone, and particularly the WAPFoR area regarding deforestation discourses, and which also affect the environment and sustainable livelihoods (P. G. Munro, 2009), (E. A. Jackson, 2015a; E. A. Jackson, 2015) - rather than finding a way forward, the 'poor' had been the target, and for which restrictions has and is still continuing to impact on their welfare (in most cases resorting to alternative adaptive means of livelihoods, for example, stone quarrying and sand-mining). The people of WAPFoR are traditionally routed in their way of life, more so on their great reliance on forest resources, and for which community initiatives (through societies or cultural groups) is part of their exhibits in the sustainable management of local forest ecosystems (Bosire, 2012; E. A. Jackson, 2015).

Government PRSP II (2008-2012) launched initiatives is now acknowledging the sustainable management of Sierra Leone's natural resource environment (forestry) as key step in the achievement of economic growth; this require an inventory of the forest environment, with the need to direct financial resources in developing productive activities such as social development within communities like 'wood-lots', backed by a World Bank government US \$24 million 5-years (2010 - 2015) project targeted at biodiversity conservation, and for which community participation in different parts of the country is needed (USAID), (GOSL, 2009). This is a key step forward in reducing the massive rate of deforestation taking place in the country, but more importantly, a step forward in ensuring that sustainable livelihoods of people, particularly poor rural residents/ households are maintained. According to UDAID (2007), also cited in ARD (Associates in Rural Development, 2010), it is also noteworthy to see the extent of international donor interventions through a 4-year 'USAID grant (US \$13.2 million) aimed at Promoting Agriculture, Governance and Environment (PAGE) project, in partnership with organisations like Associates in Rural Development (Associates in Rural Development, 2010). World Vision and the forest division at $M A F F S$. District councils and communities like WAPFoR, Koinadugu, Kono, Kailabun, and Kenema districts to pilot forest co-management scheme'. 


\section{Decentralisation: Power and Authority in the WAPFoR Area}

According to Schneider (Schneider, 2002) "Decentralised systems are those in which non-central entities play a greater role in any or all of the dimensions; such systems, non-central entities possess a greater share of fiscal resources, more administrative autonomy, and/or a bigher fraction of responsibility for political functions". Community-based initiatives on natural resource management is an example of a decentralised governance which if managed very well can bring about economic good to lives, and more importantly, the enhancement of a sustainably managed forest ecosystems, where local people are given high stake in managing their environment.

Sierra Leone as a country is managed on a centralised system of governance (a legacy inherited from colonial rule), and for which each region across the country (149 chiefdoms) is managed through a micro system of governance, for example, tribal heads as in the case with the Protectorate, and township head when it comes to the Western Area (CLGF, 2011). Whether this form of decentralisation is effectively applied to the management of forest in the country is questionable given the extent of encroachment experienced lately, thereby leaving locals with absolutely very limited chances of accessing forest land to secure their livelihoods. Despite efforts made towards decentralisation as stipulated in 2004, the current situation in the country (particularly in the WAPFoR area) is such that communities are often not fully engaged in the management / conservation process of forest amenities like Parks, with no clearly defined roles and responsibilities for local and traditional authorities (Brown \& Crawford, 2012). More disadvantageously, the lack of expected donor funding to support the country's priorities in the protection and conservation of its natural resources (forest) is posing risks to sustainable livelihood capacity for poor communities, and most importantly in the management of their communities (Brown \& Crawford, 2012).

The current state of land encroachment for housing developments in the WAPFoR area is an indication of the failure of decentralised governance, and more so the lack of priority on the part of institutional leadership (forest division at MAFFS) to give due consideration to locals, and their concerns in relation to sustainable livelihood and sustainability of the environment given recent occurrences of natural shocks like mudslide which took place on August 15th, 2017. As addressed by Munro (P. G. Munro, 2009), it is always the case that when the system (from above) has failed in its duty of governance, for locals to receive the blame in relation to the current state of 
deforestation. On a critical note, the WAPFoR community (more so decentralised leadership) is ill equipped when it comes to land usage and decentralised control, as cited by Jackson (E. A. Jackson, 2015c) from Munro (P. G. Munro, 2009) involving land feud between officials from the Ministry of Lands and forest division at MAFFS:

"Forestry wants to preserve the forest, Ministry of Lands gives out land to urban dwellers. (Interview with Government Representative; June 2008) And similarly; while the Ministry of Agriculture [MAFFS] wants to protect the forest, [...] the Lands Ministry is busy selling it. (Interview with NGO Representative June 2008)".

This situation is actually not working in the interest of poor community residents who are mostly left stranding on adaptive mechanisms (stone quarrying, etc) as the power from above is rendering them powerless on how best they can participate in the management of land in their communities.

\section{Community-based Natural Resource Management}

Having looked at the concept of community forest in earlier chapter, this section seeks to address the management of natural resources (more so forestry and which incorporate agroforestry practices) by locals in the WAPFoR area, particularly in the study locations. As addressed by Mahanty (Mahanty, Gronow, Nurse, \& Malla, 2006), Community-Based Forest Management (CBFM) which also gained momentum in regions around Africa, Asia and Latin America in the 1980s-90s has fueled the need to divert attention in the direction of poverty reduction, and the sustainable management of the forest environment. It is a true fact that community cohesiveness (through community forestry and agroforestry practices) can assist individuals and households in poor rural communities make productive use of livelihood assets to improve their livelihood capabilities (Carney, 1999).

The establishment of community based management system (be it community forestry or agroforestry) can serve as a form of safety-net for the rural poor in places like WAPFoR where the use of forest is culturally significant - mostly in the case of non-timber products like bamboos, fruits and medicinal leaves utilised for the purpose of generating daily livelihood subsistence / incomes (E. A. Jackson, 2015), (Arnold, 2001; Sunderlin, Angelsen, Belcher, Nasi, \& Wunder, 2005). Specific to the WAPFoR area, there has been a high push for community use of the Western Area Peninsula National Park (WAP-NAP) usage for Ecotourism, and which may 
also be beneficial for climate change mitigation and the long term sustainable management of its (GEF, 2012).

Currently, there is very little structured scheme set in place to address the effective management of forest in the WAPFoR area through schemes like CBFM, and given the extent of encroachment and deforestation experienced lately through building regeneration projects, it is of critical importance that move is made in the right direction to encourage community engagement, more so as a way of protecting people's livelihoods through productive use of the remaining forest. Despite the central tenet of CBFM being political empowerment with participation of local people at different levels (Hajjar, 2011), it is still coming under great criticism for its 'top-down' nature, mostly manipulated from the top, thereby making it very difficult for poor community residents to have much influence in the way decisions are made (Benatti, McGrath, \& Mendes de Oliveira, 2003), (Oyono, 2005).

A bottom-up approach may seem more favourable in order to facilitate full empowerment and participation from locals, and which may also assist in the sustainable management of the forest environment, and hence an enhancement on livelihood prospect.

\section{New Dimensions on Sustainable Forest Management}

Forest in Sierra Leone has undergone huge losses as a result of encroachment into protected areas, and the effect of this is continuously felt on the environment (land degradation and mudslide as witnessed in August. 2017) and also its direct impact on climatic circumstances (E. A. Jackson, 2015a), (IUCN, 1993). More lately, international cry in terms of addressing the abuse of natural resources such as forest has helped initiated new dimension on how best to protect the environment through activities like REDD / REDD+; this is geared towards 'Reducing Emission from Deforestation and Forest Degradation (REDD+). It is thought that through this, poor community residents will be able to address sustainable livelihood needs through payment schemes for diverting the abuse of forests into more productive activities. This idea which started in 2008 is supported by the UNEP and Forest Investment Programme (FIP), and hosted by the World Bank, with funds been pledged by countries in the Scandinavian block and mainland Europe of which Spain committed an amount of US $\$ 20.2$ between 1989-99, and with a commitment of an expansion to 40 countries between 2010-15 (E. A. Jackson, 2015b), (UNEP, 2010a). 
In Sierra Leone, this new dimension strategy was launched in July 2013 (with initial capacity building programme piloted earlier on May 2013) to assess compliance and readiness by officials to implement the scheme (Jackson, 2015a). The REDD+ initiative was seen as a form compensatory scheme to support the rural poor in reducing their destructive acts of deforesting the environment while enhancing their skills through community initiatives through community initiatives like community based forestry and agroforestry.

As in the case with Sierra Leone, the true impact of such a scheme is yet to be felt / realised after the first four years of its inception window. The legacy of the divided land tenure system (Colony which incorporate the entire Western Area and the Protectorate) created by the colonial power (the then British government) is one of the first hurdle in determining carbon emission rights, and under which payments / credits can be claimed (Conway \& O'Sullivan, 2011). The Environmental Protection Agency (EPA - guided by the EPA Acts 2008) is the institution responsible for ensuring safeguarding measures are adhered to through its monitoring of renewable resource usage (which includes forest), and hence meant that individuals and / or groups can be prohibited from converting land / forest into other purpose without the granting of proper license - in terms of the socioeconomic safeguards, reference to the Constitution (1991: Section 8.3) stressed the importance of the natural forest environment as a valuable source for people's livelihoods, which means that draft policies and laws have to address livelihood impacts seriously, particularly those affecting lives of ordinary people, thereby restricting their access to secure sustained living (Conway \& O’Sullivan, 2011).

There has been mixed messages about the true impact of the new dimension REDD+ initiatives across countries in Africa, Asia and Latin America, where it has already been implemented. In some areas / countries where the scheme was intended to leverage difficulties in terms of loss of earnings from forest, it has made life too difficult as funds were either not paid at the expected rate (due to high level of bureaucracy), and hence leaving people to struggle in meeting basic livelihood needs - it was even noteworthy that the $\$ 200,000$ initial grant expected from the 'Forest Carbon Partnership Facility (FCPF) Readiness Preparation Proposal (R-PP)' could not be accessed easily, and hence undermining the safeguarding measure (Creek \& Nakhooda, 2011), (Wing, 2014). 


\section{Conclusion}

This piece of work has emphasised on the ontological journey of the political economy and management of forest resources with particular reference to Sierra Leone (E. A. Jackson, 2015a) in this situation, the historical background of the country is reviewed with an overall approach taken in addressing the location, climate and demographics. The political economy of forest management has been exhausted with attention focused on colonial and post-colonial legislations addressed in the interest of unravelling the sustainable management of forest resources and the environment. There has been specific focus on WAPFoR in terms of its assets in addressing the needs of residents, and most importantly, effective management (with a focus on decentralisation) to address current concerns in deforestation discourses.

\section{References}

Agrawal, A., \& Gibson, C. (1999). Enchantment and disenchantment: The role of community in natural resource conservation. $W$ orld Development, 27(4).

Akiwumi, F. A. (2006a). Conflict Timber, Conflict Diamonds: Parallels in the Political Ecology of 19th and 20th Century Resource Exploitation in Sierra Leone. Development in the Twenty-first Century: Pertinent Socio-Economic and Development Issues.

Akiwumi, F. A. (2006b). Environmental and Social Change in Southwestern Sierra Leone: Timber Extraction (1832-1898) and Rutile Mining (1967-2005). . San Marcos.

Alieu, E. K. (2001). Forestry Outlook Studies in Africa In. Sierra Leone:: FAO.

Alieu, E. K. (2011). Country perspective. In. Sierra Leone

Alldridge, T. J. A. (1910). Transformed colony: Sierra Leone as it was, and as it is its Progress Peoples, Native Customs and Undeveloped Wealth. London: Seeley and Co. Limited.

Arnold, J. E. M. (2001). Poverty and Aid. CIFOR Occasional Paper. CIFOR. Associates in Rural Development, A. (2010). Sierra Leone Improves Forest Management. . Retrieved from http://www.ardinc.com/projects/project.php?id=0\&tid=1199

Becker, L. C. (2001). Seeing green in Mali's woods: colonial legacy, forest use and local control. Annals of the Association of American Geographers, 91(3), 504-526. 
Beevers, M. D. (2012). High-V alue Natural Resources and Peacebuilding (P. Lujala \& S. A. Rustad Eds.).

Benatti, J. H., McGrath, D., \& Mendes de Oliveira, A. C. (2003). Politicas Publicas e Manejo Comunitario de Rescursos Naturais na Amazonia. - Ambiente \& Sociedade, 6(2).

Bosire, T. O. (2012). The Bondo Secret Society: Female Circumcision And The Sierra Leonean State. University of Glasgow.

Brown, O., \& Crawford, A. (2012). Conservation and Peace-building in Sierra Leone, International Institute for sustainable Development.

Carney, D. (1999). Approaches to Sustainable Livelihoods for the Rural Poor. . In: Overseas Development Institute (ODI) Briefing.

CLGF. (2011). Commonwealth Local Government Forum. Retrieved from http://www.clgf.org.uk/sierra-leone.

Cole, N. H. A. (1968). The vegetation of Sierra Leone. Njala, Sierra Leone: Njala University College Press.

Commission, T. a. R. (2004). Witness to Truth: Report of the Sierra Leone Truth and Reconciliation Commission. Sierra Leone. .

Conteh, M. N. (2013). The Institution of Paramount Chieftaincy in Sierra Leone: An Introduction to its History and Electoral Process.

Conway, D., \& O'Sullivan, R. (2011). Gola Forest REDD Project: Analysis of Legal Issues. Retrieved from

Creek, A., \& Nakhooda, S. (2011). REDD+ Finance Delivery: Lessons from Early Experience. . Climate Finance Policy Brief.

Dale, P. (2008). Access to Justice in Sierra Leone: A Review of the Literature. Washington DC.

Davis, M. (2005). Forests and conflict in Cambodia. International Forestry Review, 161-164.

De Jong, W., Donovan, D., \& Abe, K. (2007). Extreme conflict and tropical forests. Dordrecht, Netherlands: Springer.

Deen-Swarray, M., Adekunle, B., \& Odularu, G. (2013). Determinant of Deforestation in Sierra Leone.

Dorward, D. C. (1981). Annual Departmental Reports Relating To Sierra Leone 1893-1961. Retrieved from Wakefield, UK:

Ebrahim-Zadeh, C. (2003). Back to Basics - Dutch Disease: Too much wealth managed unwisely. Quarterly Magazine of the IMF.

FAO. (2005). Global Forest Resources Assessment Country. Reports: Sierra Leone. . Retrieved from Rome:

FD/SL. (1913). Forestry Department of Sierra Leone. Report on the Forest Administration for the Year 1912. Retrieved from London: 
GEF, S. G. P. (2012). Promotion and Upgrade of Ecotourism Products of the Western Area Peninsula Forest Reserve in Sierra Leone. Retrieved from Sierra Leone:

Glasmeier, A., \& Farrigan, T. (2005). Understanding community forestry: a qualitative meta- study of the concept, the process, and its potential for poverty alleviation in the United States case. The Geographical Journal, 171(1).

GOSL. (2009). An Agenda for Change: Second Poverty Reduction Strategy.

GOSL, G. o. S. L. (1989). Annual report of the forest department. Freetown: Government Printers.

Guide, T. W. L. Legislation Sierra Leone. .

Hajjar, R. F. (2011). University of British Columbia.

Homer-Dixon, T. (1991). On the threshold: Environmental changes as causes of acute conflict. International Security, 16(76).

IUCN. (1993). Environmental Synopsis.

Jackson, E. A. (2015a). Deforestation in the Freetown Peninsula - A case of livelihood and biodiversity loss in the Goderich community. International Journal of Agriculture and Forestry, 2(7).

Jackson, E. A. (2015). Ethnographic Narrative of Forest Decline in the Goderich Community: The People's Perspectives. OMICS Journal Forest Research, 4(4).

Jackson, E. A. (2015b). FLEGT Mandate: its applicability and effectiveness in Sierra Leone. Journal of Applied Thoughts, 4(4).

Jackson, E. A. (2015c). Negotiating New Dimensions for Forests

Conservation in Sierra Leone. Journal of Applied Thoughts, 4(2), 85-102. Jackson, E. A. (2016). Ontological and Epistemological Discourse(s) on Sustainable Development: Perspective on Sierra Leone in the Aftermath of a Decade of Civil Unrest. Journal of Management and Sustainable Development, 8(1). doi:10.1515/msd-2016-0005

Jackson, E. A. (2016). Phronesis and Hermeneutics: The Construct of Social / Economic Phenomenon and their Interpretation for a Sustainable Society. Journal of Economic Insights - Trends and Challenges, 8(2), 1-8. Jackson, E. A. (2016). Phronesis and Resource Curse Hypothesis in PostIndependent Sierra Leone. Ilorin Journal of Economic Policy, 3(1), 1-10. Jackson, E. A., \& Conteh, P. S. Research Methods: A Resource for Students and Practitioner-researchers.

July, R. W. (1970). A History of the African People. New York: Scribner. Kaimowitz, D. (2003). Forests and war, Forests and peace. . Indonesia: CIFOR. 
Kaplan, R. (1994). The coming anarchy: How scarcity, crime, overpopulation and diseases are rapidly destroying our planet. The Atlantic.

Kinsella, E. A. (2006). Hermenentics and Critical Hermeneutics: Exploring Possibilities within the Art of Interpretation. (Vol. 7).

Konteh, W. (1997). Forest Resource Management in Sierra Leone: A Critique of Policy Formulation and Implementation. . University of Leeds.

Lane-Poole, C. E. (1911). Report on the forest of Sierra Leone. London: Waterlow and Sons Limited.

Leach, M., \& Fairhead, J. (1994). Natural resource management: the reproduction and use of environmental misinformation in Guinea's forest-savanna transition zone. IDS Bulletin, 25(2), 81-87.

Leach, M., \& Fairhead, J. (1995). Ruined settlements and new gardens: gender and soil-ripening among Kuranko farmers in the forestsavanna transition zone. IDS Bulletin, 26(1), 24-32.

Leach, M., \& Fairhead, J. (2000). Challenging neo-Malthusian deforestation analyses in West Africa's dynamic forest landscapes. Population and Development Review, 26(1), 17-43.

Lebbie, A. (2000). The Palm Wine Trade in Freetown, Sierra Leone: Production, Income, and Social Construction. . Economic Botany, 56(3), $246-254$.

Leone, V. S. (2015). Retrieved from https://www.visitsierraleone.org/backgroundinformation/history/Sierra-Leone-Background.html

MacGregor, W. D. (1942). The forest production programme in Sierra Leone. Farm and Forest, 3(3), 116-190.

Mahanty, S., Gronow, J., Nurse, M., \& Malla, Y. (2006). Reducing Poverty through Community Based Forest Management in Asia. Journal of Forest and Livelihood, 5(1), 78-89.

Mark, P. (2007). Towards a reassessment of the dating and the geographical origins of the Luso-African Ivories, fifteenth to seventeenth centuries. History in Africa, 34.

Meredith, D. (1986). State Controlled Marketing and Economic Development. The Case of West African Produce during the Second World War. The Economic History Review, 39(1), 77-91

Mula, M. G., \& Saxena, K. B. (2010). Lifting the Level of Awareness on Pigeonpea - A Global Perspectives. International Crops Research Institute for Semi-Arid Tropics.

Munro, P. G. (2008). The Politics of Deforestation on the Freetown Peninsula. Master's Thesis. King's College London, London. 
Munro, P. G. (2009). Deforestation: constructing problems and solutions on Sierra Leone's Freetown Peninsula. . Journal of Political Ecology, 16, 104-122.

Munro, P. G., \& Horst, G., H. (2011). Conserving Exploitation? A political ecology of forestry policy in Sierra Leone. . 32, 1.

Mvondo, S. A., \& Oyono, P. R. (2004). An assessment of social negotiation as a tool of local management: a case study of the Dimako Council forest, Cameroon. Scandinavian Journal of Forest Research, 19(4).

OECD. (2010). Monitoring the Principles for Good International Engagement in Fragile States and Situations Sierra Leone.

Oyono, R. (2005). Profiling Local-Level Outcomes of Environmental Decentralizations: The Case of Cameroon's Forests in the Congo Basin. The Journal of Environment \& Development, 14(3), 317-337

Reed, T., \& Robinson, J. A. (2013). The Chiefdoms of Sierra Leone. Reno, W. (1998). Warlord politics and African state. Boulder: Lynne Rienner. Reno, W. (2000). Shadow states and the political economy of civil wars. (M. M. Bergdal, M. D. M., \& C. O. Boulder Eds.).

Ribot, J., \& Cline-Cole, R. A. (1997). Encyclopaedia of Africa South of \the Sahara. In.

Ross, M. (2003). The natural resources curse: How wealth can make you poor. (I. Bannon \& P. Collier Eds. 1 ed.). Washington, D.C.: World Bank.

Rosser, A. (2006). The Political Economy of the Resource Curse: A Literature Survey. Centre for the Future State. Paper presented at the Centre for the Future State.

Schneider, A. (2002). Decentralisation. Retrieved from http://r4d.dfid.gov.uk/PDF/Outputs/Mis SPC/R76161.pdf

Shahbaz, B., \& Suleri, A. Q. (2009). Exploiting Natural Resources: Growth, Instability, and Conflict in the Middle East and Asia, Stimson Center (R.

Cronin \& A. Pandya Eds.). Washington.

Suma, M. (2009). Charles Taylor and the Legacy of the Special Court for Sierra Leone, International Center for Transitional Justice. The Hague. Sunderlin, W. D., Angelsen, A., Belcher, B. B., P., Nasi, R. S., L., \& Wunder, S. (2005). Livelihoods, Forests and Conservation in Developing Countries: An Overview. World Development, 33(9), 1383- 1402

UNEP. (2010a). Forestry Policy 2010. Sierra Leone.

UNEP. (2010b). Sierra Leone Environment, Conflict and Peace-building Assessment: Technical Report. . Chatelaine: Geneva.

UNIPSIL. (2006). Ethnic Groups of Sierra Leone.

Unwin, A. H. (1909). Report on the forestry problems in Sierra Leone. London:

Waterlow and Sons. 
USAID. United States Agency for International Development (USAID). Wardell, D. A., \& Lund, C. (2006). Governing access to forests in northern Ghana: micro-politics and the rents of non-enforcement. World Development, 34(1), 1887-1906.

Wing, G. (2014). The experience of conditional cash transfers Lessons for REDD+ benefit sharing. Info Brief. In. 